\section{Navigating the logics of changing public facilities management}

Public facilities management

\section{Ingrid Svensson}

Technology Management and Economics, Service Management and Logistics, Chalmers University of Technology, Gothenburg, Sweden, and

\author{
Martin Löwstedt \\ Construction Management, Architecture and Civil Engineering, \\ Chalmers University of Technology, Gothenburg, Sweden
}

Received 16 July 2020 Revised 2 November 2020 4 February 2021 Accepted 22 February 2021

\begin{abstract}
Purpose - The purpose of this paper is to explore how a multitude of demands and challenges faced by public facilities management organizations' (PFMOs) particularly in relation to a large building stock in need of measures' are acted upon and negotiated in practice. Specifically this study asks: What are the institutional logics (IL) that constitute the organizational context of PFMOs? How does an institutional worker navigate to create change in PFMOs?
\end{abstract}

Design/methodology/approach - Data were collected through a case study of a public facility management organization and include interviews, a questionnaire, observations and organizational documents. The analytical focus is the work of a single actor, a project manager portrayed as "the navigator" and his institutional work (IW) of developing and implementing new organizational practices, to meet current challenges and develop a more "strategic" facility management.

Findings - The complex institutional landscape faced by officials in PFMOs enforce officials responsible for implementing and developing new practices to become navigators.

Originality/value - The findings offer a rich practice-based account of the day-to-day IW carried out by actors that try to navigate complex institutional landscapes, consisting of multiple and, at times, conflicting IL. Current challenges for PFMOs are to be portrayed as multi-dimensional and the actual work to transform organizational practices in this context is highly complex, unordered and messy. The findings point towards a need for new competences and roles to tackle current challenges; geared towards integrating different logics and perspectives.

Keywords Public sector, Facilities management, Management, Organizational change, Work, Working practices

Paper type Research paper

\section{Introduction}

A central challenge for officials in public facilities management organizations (PFMOs), is to translate various political directives and demands into new (organizational) practices. These practices need to align with both the structures and logics that condition the institutional

(c) Ingrid Svensson and Martin Löwstedt. Published by Emerald Publishing Limited. This article is published under the Creative Commons Attribution (CC BY 4.0) licence. Anyone may reproduce, distribute, translate and create derivative works of this article (for both commercial and non-commercial purposes), subject to full attribution to the original publication and authors. The full terms of this licence may be seen at http://creativecommons.org/licences/by/4.0/legalcode

Funding:Formas (The Swedish Research Council for Environment, Agriculture and Spatial Planning) grant-number: 241-2012-253. CMB. Centre for leadership management in the Built Environment (Sweden) grant-number 126.

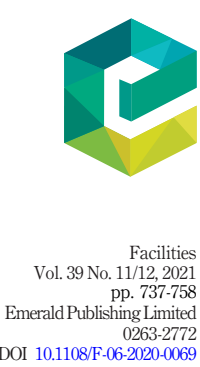


$\mathrm{F}$

$39,11 / 12$

738

landscape where these organizations operate (Galamba et al., 2012; Ramskov-Galamba and Nielsen, 2016; Hemme et al., 2020).

Today, a vast majority of the public building stock worldwide is outdated and in need of renovation or even demolition (Uotila et al., 2019) as a result of insufficient maintenance (Hopland, 2016). The renovation and management of the public building stock is taking place amidst multiple and sometimes competing demands for efficient, financially sound, and at the same time, sustainable operations (Hill et al., 2013) variously distributed across field, organizational and project levels (Gluch and Svensson, 2018) and strained between short-term and long-term perspectives and priorities (Barett, 2000; Hill et al., 2013; Higham et al., 2015). Furthermore, practices and ethics of PFMOs are increasingly influenced by the general adoption of business-related logics [1] by public organizations (Ramskov-Galamba and Nielsen, 2016; Haugen and Klunseth, 2017). In addition to this, the management and renovation of the (current) European public building stock is argued to play a crucial role for the achievement of the European Union's 2050 decarbonization goals (Nielsen et al., 2016); therefore, practices need to align with sustainability logics.

It has been recognized that PFMOs need to develop new kinds of (strategic) organizational capabilities (Junghans, 2013; Olsson et al., 2015; Ramskov-Galamba and Nielsen, 2016; Svensson, 2018; Jensen et al., 2018; Bröchner et al., 2019; Pardalis et al., 2019) to manage this growing number of challenges. However, little is known about how such work is conducted in practice and how PFMOs' officials are conditioned by the specifics of the multiple logics milieu (Galamba et al., 2012; Hill et al., 2013; Boyd and Schweber, 2017; Campbell, 2017; Castán Broto, 2019).

Previous research on strategic efforts has focused more on the organizational level and on private organizations. For example, Kaya et al. (2005) developed a framework for strategic facilities management and elaborated on the different roles that FM organizations need to adopt for these organizations to realize their full (strategic) potential.

In addition, much of the aggregated research on building renovation and maintenance has been characterized by explorations and focuses on different challenges treated separately (Karvonen, 2013; Palm and Reindl, 2016; Nielsen et al., 2016; Palm and Reindl, 2017). However, the actual challenge for officials working in these contexts appears to be less about solving a number of separate problems (usually portrayed as juggling two dichotomies) and more about navigating a multitude of different (institutional) logics and perspectives to develop integrated practices and solutions (Bordass and Leaman, 2013; Junghans, 2013; Thoresson, 2015; Tucker et al., 2016; Gluch and Svensson, 2018) that are adapted to fit each individual organization and its situated institutional surroundings, rather than any normative template of "best practices" (Hopland and Kvamsdal, 2019).

The position in this paper is that the emerging transformation in PFMOs can be conceptualized and explored as an "institutional change" during which individual actors engage in "institutional work (IW)" (Lawrence and Suddaby, 2006). Drawing on rich qualitative case study data (Flick, 2014), a practice-based institutionalism lens (Smets and Jarzabkowsk, 2017) is used to elucidate how a PFMO official navigates through a multitude of different institutional logics (IL) and perspectives while attempting to develop and implement new organizational practices, referred to by the organization as "strategic facilities management". Two interrelated research questions have guided this research:

RQ1. What are the IL that constitute the organizational context of PFMOs?

RQ2. How does an "institutional worker" navigate to create change in PFMOs? 


\section{Theoretical frame}

\section{A practice perspective to institutional logics and change}

Institutional theory and, especially, the sub-theories such as practice-oriented IL and IW have been considered particularly fitting to frame and understand how changing local-level practices are conditioned by their wider institutional contexts (Lawrence and Suddaby, 2006; Zilber, 2013; Lindberg, 2014; Smets et al., 2017). These perspectives give micro - rather than macro - phenomena precedence (Powell and Colyvas, 2013) and, therefore, recognize institutional change as something that emerges from and in practice (Lounsbury and Crumley, 2007; Smets et al., 2017). Specifically, practice-based institutionalism seeks to advance our understanding of how the multiple ILs that constitute any institutional context - in our case, a PFMO - are linked to the actual IW required to change practices in the given context (Smets et al., 2017).

Every institutional context is mediated by a certain set of ILs, which may be seen as those "material practices and symbolic constructions" (Friedland and Alford, 1991) that shape meanings; provide legitimacy; determine issues, problems and solutions; and impact change (Thornton, 2002; Reay and Jones, 2016; Goodrick and Reay, 2011). On a day-to-day basis, the range of actors that work in any given institutional context continually face situations that call for various actions, which are, in turn, guided by a multitude of embedded ILs (Fred, 2019). The more practice-oriented studies posit that these ILs never exist per se but are continuously reconstructed in practice; that is, they become relevant for practice only when they are enacted in practice (Lindberg, 2014).

While many of the more macro-oriented contributions on institutional change have tended to focus on the conflicts and contradictions between a set pair of contrasting ILs (Friedland and Alford, 1991; Thornton and Ocasio, 2013), a recent stream of practice-based studies have highlighted that institutional change is better characterized by the dynamics amongst a multitude of different ILs. These include, for instance, how multiple logics co-evolve (Dunn and Jones, 2010) and facilitate each other (Goodrick and Reay, 2011) or how logics are used strategically to influence ongoing change processes (Venkataraman et al., 2016). Different logics can thus be emphasized and enacted in different stages of a change process for individual actors to influence a preconceived result (Lindberg, 2014; see also Fred, 2019).

To understand these messy realities of emergence and adaptions of ILs, it becomes imperative to focus on practices (Smets et al., 2017; Lindberg, 2014) and to pay attention to historical contingencies, as well as how ILs are translated at different organizational levels (Zilber, 2013). Following this, it is reasonable to expect the multitude of emerging and existing logics and demands that are imposed on today's PFMOs (such as sustainability, energy performance, financial performance) to be subjected to substantial negotiations and tensions.

Focusing on the level of practice, it is possible to increase the understanding of how actors situated in PFMOs work to manage a multitude of different ILs through IW (Gluch and Svensson, 2018).

\section{Working within complex institutions}

The theoretical construct of IW encapsulates the purposive actions aimed at creating, maintaining and/or disrupting institutions (Lawrence and Suddaby, 2006). It has been used to frame an understanding of how, why and when human actors engage in work that has the potential to shape and change institutions (Hampel et al., 2017) and, furthermore, how this work can be linked to outcomes on various analytical levels (Gluch and Svensson, 2018).

Attempting to navigate change through a complex institutional landscape, is an increasing challenge for organizations today (Dahlman and Grosvold, 2017; Pemer and Skjølsvik, 2018), and thereby, also concerning a large number of individual actors who work 
$\mathrm{F}$

$39,11 / 12$

740

in these organizations. Especially, in public organizations, challenges arise when competing logics are represented among different internal organizational stakeholder groups (Hemme et al., 2020).

Rather than giving precedence to only a few "influential actors" (Battilana et al., 2009), an IW perspective directs the attention towards how "ordinary" workers set out to do "ordinary" work against the backdrop of larger institutions (Lounsbury and Crumley, 2007; Lawrence et al., 2011; Smets and Jarzabkowsk, 2013). This work is not always planned or rational but, many times, it is better characterized as responses that are applied ad hoc in relation to unanticipated situations (Powell and Colyvas, 2013; Lawrence et al., 2010). As such, an IW perspective enables a detailed understanding of the complex, reflexive and recursive relationships that ordinary individuals experience between themselves and the institution(s) they encounter or are part of (Zietsma and McKnight, 2009; Lawrence et al., 2011), as well as the broad array of factors that affect individuals' abilities to shape these institutions (Hampel et al., 2017).

One important dimension of the actor-based ability to shape institutions is related to legitimacy. Researchers have explored how actors' different degrees of legitimacy are related to their particular roles in institutions (Ludvig et al., 2013) and how this legitimacy is created ongoingly through IW (Dahlman and Grosvold, 2017; Gluch and Bosch-Sijtsema, 2016). Ludvig et al. (2013), for instance, pointed towards the difficulties involved in creating legitimacy for practices related to energy efficiency, specifically within PFMOs. They highlighted the importance of possessing discursive competencies to frame and anchor political directives regarding energy efficiency in local practice. In the same vein, Gluch and Bosch-Sijtsema (2016) pointed out similar difficulties for environmental managers in the construction industry more broadly. They concluded that these individuals often lack the legitimacy needed to implement new organizational practices that support the sustainability agenda. Instead, they get "locked in" and restricted to participation in work that merely maintain existing institutional practices. Dahlman and Grosvold (2017), by contrast, showed how environmental managers in private firms in the UK were able to implement new (environmental) practices by embedding the environmental logic alongside a dominant market logic. However, to do so successfully, they needed to combine actions variously aiming at creating, maintaining and disrupting institutionalized practices (Lawrence and Suddaby, 2006; Battilana and D’Aunno, 2010).

\section{Method}

\section{Description of PublicPrem}

Data were collected at a PFMO (hereafter labelled "PublicPrem") in the city of Gothenburg, Sweden. PublicPrem serves 10 different city areas (CA) and deals with construction procurement as well as the management of a large stock of various public premises including schools, preschools and housing for elderly persons and those with special needs. The functional unit, "Facilities Secretariat", is responsible for the strategic planning of municipal premises in the city. The Municipal Facilities Board (MFB) comprises layperson politicians mandated to make decisions regarding the focus, goals, policies and directions governing both the Facilities Secretariat and PublicPrem's operations.

In 2015, the MFB commissioned PublicPrem with the task of developing a long-term strategy for the renovation of all their premises built between 1950 and 1970. Following this, a small group of people began to develop ideas about how to transform current organizational practices to be more "strategic". They were given a somewhat "free rein" but within a specific focus on "energy-efficient renovation". This project is hereafter labelled the strategy project and includes a pilot project, which was a smaller project aimed at testing 
new ideas developed within the frame of the strategy project, which will be explained in detail below.

The workgroup was led by a project manager (a facility manager by training) who, hereafter, will be referred to as "the navigator", to depict the nature of his work to drive organizational change in this complex institutional landscape. The focus for our findings will be the work of this individual as it unfolds in relation to his situated context. Specifically, we explore in detail his efforts to develop and implement more-strategic organizational practices, to manage the combined multiple challenges imposed on the organization. These challenges include the following:

- a large building stock in need of renovation;

- a pressing need for new premises;

- a better overview of the current building stock; and

- an overall adaptation to new and stricter sustainability goals - altogether under an overall pressure to be increasingly "financially efficient".

The decision to focus specifically on the perspectives and actions of this particular navigator was made because he worked in a role that accentuated the consideration of the whole multidimensional institutional milieu.

Together with an assembled team, the navigator developed and tested ideas for new organizational practices in a pilot project running from March 2016 to September 2016. The pilot-project team consisted of the navigator, a representative from PublicPrem (a facility manager), a representative from the Facilities Secretariat (a planning manager), a consultant (specialized in construction finance) and a representative from the specific CA (development leader for facilities) in which the pilot project was conducted. In the early stages, a sustainability manager was also part of the team but was later replaced by a financial manager.

Initially, the strategy project focused only on the energy-efficient renovation of preschools, but as it evolved, the scope expanded to entail all types of premises in the city and a multitude of other perspectives and performance measurements.

Organizing the work according to strategic facilities management would result in several organizational consequences. The first is a higher demand on the facilities managers to be able to assess their buildings and make decisions regarding which of four options to choose for each building, including demolition or extending the life of the building for 5, 10 or 20 years. If more strategic facilities management is implemented, the role of practitioners involved in renovation will change from being urgency-driven ad hoc fixers to strategic planners.

Secondly, once implemented, the new model will result in increased collaboration between PublicPrem and the Facilities Secretariat, and strategic decisions previously made by officials at the Facilities Secretariat will be made by officials in PublicPrem.

Thirdly, facilities managers will need to plan for evacuation during renovation and/or rebuilding into existing buildings or plan to build newer premises that are larger than (currently) needed so these can be used for evacuation. Previously, PublicPrem has used temporary pavilions to address a pressing shortage of premises, an approach that, according to employees at PublicPrem, is neither economical nor environmental defendable in the long term.

Finally, the way of working will entail a shifting focus away from having separate plans for different CAs towards having a "grand plan" for the city's total public building stock. All in all, the proposed measures were labelled "strategic facilities management" by the navigator and the rest of those working with the strategy project.

At the end of May 2017, the work with the strategy project was summarized and presented to the top management at PublicPrem by the navigator, and with that, the project 
$\mathrm{F}$

$39,11 / 12$

742

ended. The aim was then to move from project to process to embed the new organizational practices proposed and first tested in the pilot project.

Although the navigator managed to get everyone onboard and push the project forward, in 2020, many elements have yet to implemented, such as the reallocation of power between the Facilities Secretariat and PublicPrem and grand plans for the entire city. However, one element that has been implemented is the practice of consistently thinking of evacuation into existing buildings during renovation and/or re-building as an option rather than using temporary pavilions, together with an awareness of the usefulness and benefits of a deeper knowledge of the building stock.

\section{Study design and data collection}

We conducted a qualitative single case study of PublicPrem (Flick, 2014) since this provided an opportunity to study the process through which new public facilities management practices were developed, legitimized and (presumably) embedded, foremost by the navigator within his specific context (Dyer and Wilkins, 1991). Data were collected by the first author of this paper and spanned a period of four years (2016-2020); for an overview of the data collection timeline (Table 1).

\begin{tabular}{|c|c|c|c|}
\hline Activities & Year & Methods adopted & $\begin{array}{l}\text { Reasons for conducting the } \\
\text { activities }\end{array}$ \\
\hline $\begin{array}{l}\text { Closely following the } \\
\text { development of the strategy } \\
\text { project, specifically shadowing } \\
\text { the pilot-project and the } \\
\text { navigator. }\end{array}$ & 2016 & $\begin{array}{l}15 \text { open-ended interviews, } \\
\text { audio-recorded and } \\
\text { transcribed verbatim, } \sim 1 \mathrm{~h} / \\
\text { interview } 8 \text { observations of } \\
\text { meetings and presentations } \\
\text { Small talk during coffee } \\
\text { breaks + organizational } \\
\text { documents }\end{array}$ & $\begin{array}{l}\text { Following the development of } \\
\text { new facility management } \\
\text { practices in a given context (i.e. } \\
\text { PublicPrem) }\end{array}$ \\
\hline Follow-up interviews & 2017 & $\begin{array}{l}7 \text { open-ended interviews, } \\
\text { audio-recorded and } \\
\text { transcribed verbatim, } \sim 1 \mathrm{~h} / \\
\text { interview }\end{array}$ & $\begin{array}{l}\text { To gain an understanding of if } \\
\text { and how new practices were } \\
\text { implemented and/or embedded } \\
\text { within the organizational } \\
\text { nexus }\end{array}$ \\
\hline $\begin{array}{l}\text { Email survey to all facilities } \\
\text { managers at PublicPrem }\end{array}$ & 2017 & Four questions sent via email & $\begin{array}{l}\text { To explore how the outcome, i. } \\
\text { e. "strategic facilities } \\
\text { management", was perceived } \\
\text { and understood amongst } \\
\text { facility managers (FMs) at } \\
\text { PublicPrem as it was their task } \\
\text { to implement and work } \\
\text { according to the new practices }\end{array}$ \\
\hline Interviews with the navigator & $\begin{array}{l}2016 \\
\text { to } \\
2020\end{array}$ & $\begin{array}{l}11 \text { interviews and } \\
\text { conversations with the } \\
\text { navigator }\end{array}$ & $\begin{array}{l}\text { To gain deeper insight into his } \\
\text { perspective and reflect on when } \\
\text { he left the organization to } \\
\text { enable further reflections and, } \\
\text { thereby, enhance the study's } \\
\text { validity }\end{array}$ \\
\hline Workshop with 9 participants & 2019 & $\begin{array}{l}\text { Discussions in smaller } \\
\text { groups }\end{array}$ & $\begin{array}{l}\text { Enhance validity of the case } \\
\text { study }\end{array}$ \\
\hline Interviews & 2020 & $\begin{array}{l}\text { Interviews with two of the } \\
\text { participants from the } \\
\text { workshop }\end{array}$ & $\begin{array}{l}\text { Enhance validity of the case } \\
\text { study }\end{array}$ \\
\hline
\end{tabular}

Table 1.

Overview of the data collection activities, methods, time period and reasons for conducting the activity 
The groundwork for data collection and analysis was inspired by the inductive method developed by Gioia et al. (2013). Accordingly, we employed multiple data collection methods (including interviews, a questionnaire, "shadowing" the navigator (Czarniawska, 2014), observations of meetings and presentations, and analysis of organizational documents) and we made a conscious attempt to adopt and use the respondents own descriptions (such as "strategic facilities management"), as opposed to our own, to increase our understanding of their lived organizational experiences. However, as we used theories to guide the research questions, interview questions and data analysis, the research was not purely inductive; instead, a continuous movement between theory and empirical data meant the research approach was abductive (Dubois and Gadde, 2002).

Observations. Data collection was inspired by the stream of research labelled "ethnography". As ethnography is "the study of situated action within its broader context" (Zilber, 2020, p. 7), this data collection method was deemed suitable given the aim of the study.

The navigator's work during the unfolding of the strategy project was closely studied from the initial phase throughout the project's prolonged development and (aimed) implementation in, first, one city area (pilot project) and later the entire organization. As the interest lay in investigating specific issues rather than providing a holistic cultural analysis, we used a strategy for ethnographic research that Zilber (2020) described as "exploring the micro-foundations at pivotal institutional moments" (p. 15), meaning that specific, significant (institutional) episodes were targeted, i.e. we were focusing on moments in a process during which certain institutional dynamics were more evident, such as the introduction of new practices in PublicPrem (Zilber, 2020).

Not every meeting that the navigator attended during the pilot-project development was observed, and he was not shadowed everywhere. Instead, he sent invitations to the all the meetings he thought would be of interest for the research. The meetings attended concerned organizational and planning issues related to the pilot project, aimed to introduce this concept outside of the pilot-project group.

Hence, the type of ethnography adopted was a "focused" one in which specific aspects of a field were studied with a specific purpose in mind; background knowledge informed the research question; informants served as key participants with their knowledge and experience; and, in addition, purposeful field visits using particular timeframes or events were conducted (Higginbottom et al., 2013).

Interviews. To capture the different logics and work practices at play throughout the organization, interviews were conducted in different parts of the organization(s), at both managerial and operational levels. In 2016, semi-structured interviews were conducted with 11 persons, including all members of the pilot-project group and other representatives from PublicPrem with insight into the pilot project and its connected ideas.

To follow up on the project's implementation, all interviewees from 2016 were invited to participate in follow-up interviews about a year and a half after the initial data collection began. Of the 11 previously interviewed, five agreed, while six were unable (rather than unwilling) to participate in the data collection for various reasons. Two additional employees at PublicPrem were interviewed instead (see Table 2 for an overview).

For both rounds of interviews, a semi-structured approach was used to allow the interviewees to talk openly within the boundaries of a number of set themes. For the first round of interviews, the themes were:

- the strategy project's development, implementation, goals and interrelations;

- the timing and facilitation of organizational practices; and

- the actors involved and their specific roles and work throughout the change process. 
$\mathrm{F}$

$39,11 / 12$

744

Table 2.

Overview of interviewees in

PublicPrem (and its

organizational

surroundings)
Interviewee Organization

Times interviewed: round 1

Times interviewed

Sustainability manager

Head of PublicPrem

Development leader for facilities

Planning manager (premises)

Consultant within the building sector

Facilities manager 1

Facilities manager 2

Project manager 1

Project manager 2

Financial manager

Head of facilities managers

Improvement manager

Project manager 3
PublicPrem

PublicPrem

City Area

Facilities Secretariat

Consultant

PublicPrem

PublicPrem

PublicPrem

PublicPrem

PublicPrem

PublicPrem

PublicPrem

PublicPrem round 2

$\begin{array}{ll}2 & 0 \\ 1 & 0 \\ 1 & 0 \\ 1 & 1 \\ 1 & 1 \\ 1 & 1 \\ 0 & 1 \\ 1 & 0 \\ 1 & 0 \\ 1 & 0 \\ 1 & 1 \\ 0 & 1 \\ & 1\end{array}$

In addition, each interview included follow-up questions that were tailored to their specific roles.

For the second round, the interviews consisted of follow-up questions regarding the strategy project, such as: How did everything turn out? Was it as expected or different? Why or why not? Can you give examples of actual organizational changes resulting from the strategy project?

The theoretical concepts of IL and IW were kept "in the back of the mind" of the researcher during the interviews and, in that way, provided a structure for the interview guide. During the interviews, the researcher watched for specific behaviours, i.e. "work" conducted, and followed up answers to questions so that the respondents could link this work to wider phenomena in the institutional surroundings (i.e. capturing the relationship between the work and [presumed] logics).

Questionnaire. From the interviews in the second round, learning took place in regard to "strategic facilities management", as a new organizational practice. Given the multiple logics that constituted the context in which the strategy project unfolded, it was interesting to explore how the outcome, i.e. strategic facilities management, was perceived and understood amongst all the facility managers (FMs) at PublicPrem (meaning those who were expected to implement and work according to the new practices), not only the ones who were interviewed. Thus, about two years after the initial data collection began and strategic facilities management was starting to be implemented, a four-item questionnaire was emailed to all 13 FMs (eight responded) concerning their perceptions regarding the new ways of working and what they considered to be the actual changes following the implementation.

Organizational documents. Organizational documents were also used as data. These consisted mainly of documents concerning the strategy project and included those used by the project team to communicate to the politicians, as well as the documents and PowerPoint presentations that were used internally. Using written sources such as organizational documents, articles from Swedish newspapers and national and regional policy documents was seen as complementary to other data collection methods.

Ongoing conversations with the navigator. In addition, between 2016 and 2020, a total of 11 interviews and conversations were conducted with the navigator, both during and after the development and implementation of strategic facilities management. These discussions 
were conducted face-to-face, through e-mail, by skype and by phone. The navigator left PublicPrem in late 2017 to work for another PFMO; however, contact between the navigator and this paper's first author was maintained up until 2020 and beyond.

\section{Data analysis}

A continuous movement between the empirical and the theoretical (Dubois and Gadde, 2002) made it possible to understand how actions across multiple levels and the development of new practices were conducted by the navigator against the backdrop of several logics.

The analysis was divided into two main parts. In reality, these overlapped; however, for the sake of clarity, they are presented here as corresponding to two distinct aspects of our findings (Figure 1).

Firstly, to identify the ILs in the field, we followed Reay and Jones (2016) and considered "logic" to be the pattern and interplay among symbols, beliefs, norms and practices that guide people in an institutional setting, thus, socially constructed values and beliefs that guide behaviours. Such logics can be revealed by language and practices and manifested as symbols and materials (ibid.). What Reay and Jones (2016) would label "pattern inducing" was applied, meaning that the main approach was bottom-up as we were "analyzing and coding (grouping) the text in ways that show behaviour or beliefs guided by particular logics" (Reay and Jones, 2016, p. 449), rather than attempting to fit the findings into predetermined logics.

Thus, the first step in our analysis sought to identify the ILs that mediated practice in PublicPrem in relation to the strategy project (Table 3). Here, we used notes from observations of meetings together with the interviews and organizational documents.

In our second step, data analysis was aimed at exploring the perspective of one particular institutional worker, the navigator, as he attempted to work his way through these multiple ILs, to drive change at PublicPrem. In this step, coding was first inductive in the sense that, with open minds, we searched for strategies and approaches used by the navigator. As we

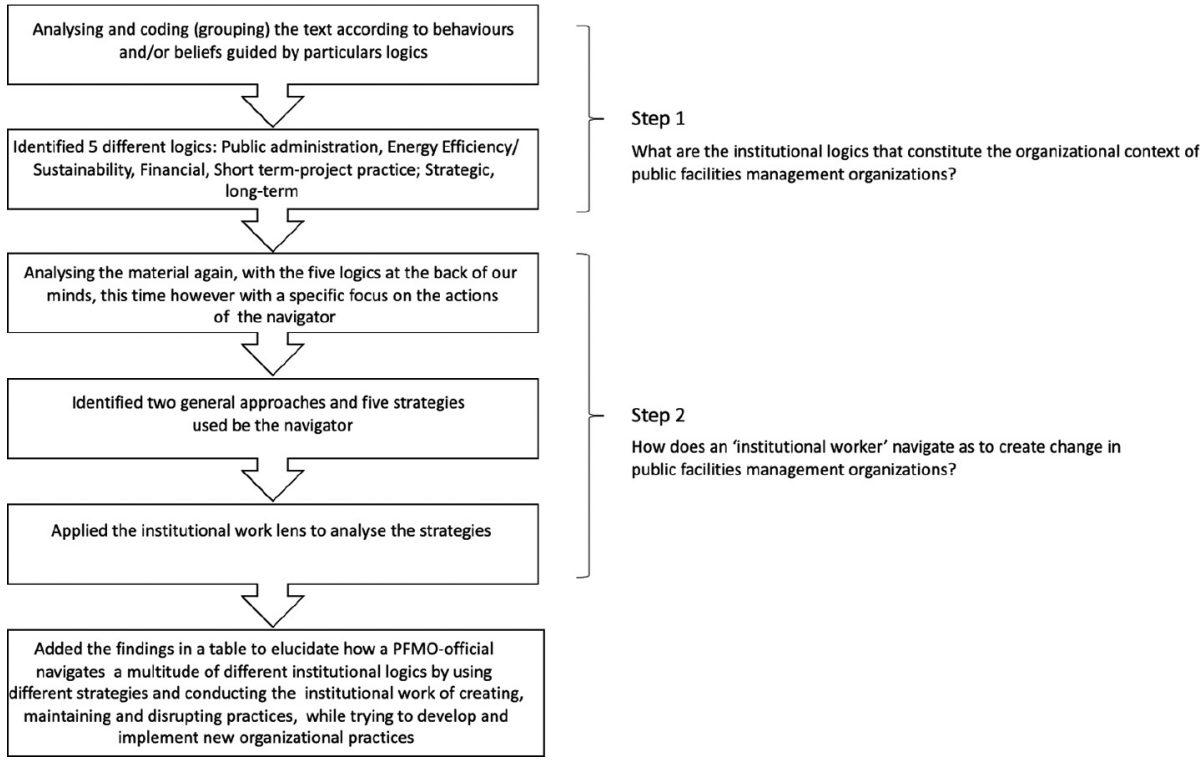

Public facilities management 
$\mathrm{F}$

$39,11 / 12$
Characteristics of logics and aspects related to the strategy project

Short term, project practice perpective:

Short-term, project-practice perspective: "

Current organizational logic within

PuublicPem when the strategy

project started

The common practice was reactive,

ad-hoc, short-sighted problem-solving to handle the most acute problems

No systems or organizational

processes for long-term planning and

(facilities) management

Professional logic

An "inactive" logic

(Some project managers [engineers] and FMs had previously been trying to develop working practices on their own to adhere to their idea of what their profession was about, which, according to them, was long-term planning prior to the strategy project. However, those ideas were not adopted by the organization and stayed as single projects, thus not affecting the organizational "structure")

Strategic, long-term logic

The logic that the strategy project was aimed to introduce
Quotes illustrating the practical enactments of the logics

"patch and mend" logic

"We could continue to 'patch and mend' until the next ice-age, but we should not if we are to achieve our different goals". (Financial manager)

“...we replace some windows, we replace some roofs, we do a little bit of those things like we usually do...." (Facilities manager 1)

"All we do is 'put out fires' and handle the most acute things". (Facilities manager 2)

"... as we could only "put out fires" and handle the most acute things, we could not work according to our professional training". (Facility Manager 2)

"In a perfect world we would only have carried out large, planned, measures and nothing 'acute'. That is really a given [considering my educational background as Facilities manager]". (Facility manager 2)

"We have not treated the facilities (within PublicPrem) as you would do, given your knowledge as a facilities manager, with your own house. We have not been able to do that; we have not had the resources in terms of money and time". (Financial Manager)

"People come and go in these type of [public] organizations... you become cynical. . . if you try to develop long-term solutions, then you need to have some processes and documents in place. . that has not been the case, so you have not been able to do a 'proper' job”. (Project manager 1)

"As a result of parts of the pilot project being implemented in the organization, the facilities managers (and the entire PublicPrem) have begun to think in new directions, more strategic and long-term, and are, as a result of that, developing new practices". (the navigator) "With this project, it shows an awareness across the organizational nexus that long-term planning and foresight when it comes to facilities management. and facilitates providence leads to better decisions". (the navigator)

"What the previous way of working has focused on is: "I have a house and I will maintain it and I do that for a very long time". Now instead: "I have a house I will maintain over a very long time, and then I will look at what happens after that time is up. What should I do then? And then I'll have different suggestions that will go into

(continued)
Table 3.

Illustrative data supporting the existence of the six identified IL 
Characteristics of logics and aspects related to the strategy project

Energy efficiency/sustainability logic Prevalent mostly at the managerial and political levels of the organizational surroundings of PublicPrem

(Energy efficiency was, in the end, only one aspect of the strategy project, i.e. not the core idea.)

\section{Financial logic}

Prevalent mostly at managerial level and among politicians

(In the beginning of the strategy project, calculations to show energy efficiency were made; later, the calculation was focused on saving money.)

\section{Public administration logic}

Present before, during and when the strategy project was finished throughout the entire PublicPrem and also present in its surrounding organizations
Quotes illustrating the practical enactments of the logics

each other and such... now we are in a position in which this is possible to be realized". (Development leader for facilities)

"It was like. . . if we are to meet the energy efficiency targets, they must be included in in the "plan for premises"; they have to be included; it has to be one aspect". (the navigator)

"[The project] has developed into something else. .." not focusing on energy efficiency. (Financial manager)

"If you do not keep the budget in public operations, you have no career opportunity". (the navigator)

"The economical sustainability is absolutely the overall aim of the work with strategic facilities management".

(Improvement manager)

"This whole energy-efficiency thing was also that we could calculate the benefit, that it is less expensive". (Financial manager and the navigator)

"Cooperation between the different organizations within the project is difficult since there is currently, like always in public organizations, an overview of the organization of the different administrations. This means that all administrations need to argue for their use and uniqueness". (the navigator)

"Everyone is waiting for the next municipal board meeting that can put everything upend". (the navigator)

"Organizational issues regarding the administration might hinder the new practices to be developed. . . for example, will the schools and preschools be in the same administration?" (Head of PublicPrem) 
$\mathrm{F}$

$39,11 / 12$

\begin{tabular}{|c|c|c|c|}
\hline $\begin{array}{l}\text { General } \\
\text { approaches }\end{array}$ & Strategies & Logics managed & Forms of IW \\
\hline \multirow[t]{2}{*}{$\begin{array}{l}\text { Zooming } \\
\text { in }\end{array}$} & $\begin{array}{l}\text { Keeping cool and } \\
\text { carrying on }\end{array}$ & $\begin{array}{l}\text { Public administration } \\
\text { (patch and mend) }\end{array}$ & $\begin{array}{l}\text { - Disrupt Ignoring established } \\
\text { practices and, thereby, being able } \\
\text { to continue to create (and } \\
\text { implement) new practices }\end{array}$ \\
\hline & Individuating & $\begin{array}{l}\text { Energy efficiency/ } \\
\text { sustainability Financial } \\
\text { Patch and mend }\end{array}$ & $\begin{array}{l}\text { - Create Choosing members for the } \\
\text { project group, enabling new ways } \\
\text { to collaborate across } \\
\text { organizational borders, and } \\
\text { attacking the taken-for- } \\
\text { grantedness of working ad hoc in } \\
\text { PFMOs by aligning with a certain } \\
\text { group of individuals }\end{array}$ \\
\hline \multirow[t]{2}{*}{$\begin{array}{l}\text { Zooming } \\
\text { out }\end{array}$} & $\begin{array}{l}\text { Adapting to the various } \\
\text { parts of the } \\
\text { organization and its } \\
\text { surroundings }\end{array}$ & $\begin{array}{l}\text { Energy efficiency/ } \\
\text { sustainability Financial } \\
\text { Strategic long term Patch } \\
\text { and mend }\end{array}$ & $\begin{array}{l}\text { - Create Making the aim of the } \\
\text { project open for interpretation and, } \\
\text { thereby, enabling a diffusion of } \\
\text { practices by making it everyone's } \\
\text { concern Maintain By "ignoring" or } \\
\text { downplaying the energy-efficiency } \\
\text { aspects of the project, the } \\
\text { navigator selected one } \\
\text { institutionalized practice over } \\
\text { another (when meeting with the } \\
\text { officials). Disrupt Selecting and } \\
\text { promoting practices other than } \\
\text { those that were prevalent before, i. } \\
\text { e. developing long-term instead of } \\
\text { short-term practices }\end{array}$ \\
\hline & $\begin{array}{l}\text { Emphasizing collective } \\
\text { efforts }\end{array}$ & $\begin{array}{l}\text { Strategic long term (Public } \\
\text { administration) }\end{array}$ & $\begin{array}{l}\text { - Create Presenting the project } \\
\text { group as a unified entity and, } \\
\text { thereby, legitimizing new practices }\end{array}$ \\
\hline
\end{tabular}

Table 4.

Overview general approaches, strategies, logics managed and the

navigator's IW

\section{8}

paper together with two other colleagues. It was a whole-day event attended by nine representatives from different organizations, either PFMOs or organizations working closely with such organizations, plus one organizational researcher who specializes in FM. All participants recognized the setting narrated in this paper, i.e. the multiple logics milieu and the complex organizational setting, and they stated that the reality of the navigator was their reality as well. In addition and further enhancing the validity of our results, two participants at the workshop were interviewed in 2020 to elaborate on the results presented and discussed at the workshop. They were working at two PFMOs in different locations in Sweden; however, one had begun working at PublicPrem after the follow-up interviews took place but left the organization in 2019. Both agreed that the multiple logics milieu represents PFM in general and not only PublicPrem. They also explained that their current organizations were not working according to the ideas presented in strategic facilities management, although they clearly saw a need for it.

During the interviews and fieldwork, a flexible interview guide was used; in some instances, the interviews were more like conversations, and this captured what was going on at the time. In addition, several informants were re-visited and interviewed again (Gioia et al., 2013). The research quality was further enhanced by ongoing contacts with the navigator, who was asked, among other questions, about this 
specific epithet; confirming that it indeed reflected the characteristics of his work at PublicPrem.

\section{Findings}

The findings include illustrative episodes of how the navigator worked to develop and implement the strategy project (including the pilot project) by means of navigating and, thereby, managing the different ILs that constitute PublicPrem. To pursue his goal, the navigator used two overall approaches, zooming in and zooming out, with four distinct strategies while conducting the IW of creating, disrupting and maintaining practices (Battilana and D'Aunno, 2010). In reality, these approaches overlapped at times, but we argue that they serve to emphasize a central aspect about navigating and doing IW in PFMOs. The findings are summarized in Table 4.

\section{Zooming in}

Keeping cool and carrying on. Being a public organization affected the strategy project in several ways. To begin with, a basic premise for the new practices was that organizational units (administrations) needed to collaborate and put aside their own interests for the common good. However, this was particularly difficult at the time of the strategy project since:

[...] there is currently, like always in public organizations, an overview of the organization of the different administrations. This means that all administrations need to argue for their use and uniqueness [...] which makes collaboration difficult as one project member explains.

The political laypersons and politicians that carried the decision mandate for mandatory demands imposed on the PFMO took their time making decisions that were of importance for the progress in the strategy project. This was due, in part, to administrative reasons but also because their decisions, in turn, were "sequenced" together with broader decisionmaking concerning a reorganization of the whole city administration.

Thus, the strategy project was likely to end up like other change projects, where nothing happens and things get "locked up", as stated by one project member early on:

Well, usually in these kind of projects (i.e. change and improvement projects) everything gets "locked up" simply because everyone is waiting for the next municipal board meeting that can upend everything.

To manage this, the navigator posed the strategy of ignoring the old ways of managing the public administration logic. For example, when asked directly after a meeting with the heads of the Facilities Secretariat and PublicPrem, in which the navigator was, in fact, denied approval to move the strategy project forward in accordance with current plans, he "kept cool": "We should not worry too much about that (the lack of approval); maybe there are things going on at the top management's level that I do not know about".

It is easy to imagine how such uncertainty could have instilled a lot of ambiguity for committing to progress in the strategy project. However, the navigator did not bother to wait for the politicians to approve of his ideas but instead carried on with the project according to the immediate plan. The navigator offered the following reflections regarding this decision:

If this new way of working is to be implemented formally and all the way, in the entire city, with all kinds of premises, the politicians need to agree upon the ideas. However, in the current stage, we just continue working as we do. Even if the politicians have not said yes yet [... . we just continue. 
$\mathrm{F}$

$39,11 / 12$

750

Outwardly at project meetings and presentations, the reoccurring rhetoric of the navigator (and the project team) was that the project was continuing to progress according to plan, even though it was not aligned with decisions on the political levels.

Thus, "keeping cool and carrying on" refers to the navigator's ability to focus only on what was right in front of him and his team on the immediate project agenda and based on this carrying on as planned, while temporally disregarding and ignoring the pressures and tensions deriving from the strategy project's broader institutional surroundings. This is proposed to lead to disruptions of established practices since the strategy project moved on (and then, in turn, created change).

Individuating. The strategy project was initiated due to a demand from the politicians to focus on energy efficiency. However, rather than focus on developing energy-efficient practices and introducing such logic within the organization, this issue was left behind in favor of practices associated with another logic that was governing operations within PublicPrem: the financial logic. At the individual level, this manifested itself in the following ways: a dedicated sustainability manager who was involved in the planning phases of the strategy project was rather abruptly removed from the project team on the basis that she was associated with the energy efficiency/sustainability logic, a logic that was perceived to create too much tension with the financial underpinnings of the project. This was described by one of the other project group members who supported removing the sustainability manager from the project group in this way:

In this group, we did not see that there was any direct bearing on [the sustainability manager's] area $[\ldots]$ it's more the financial sustainability that matters [...]. That is the absolute overall aim in strategic facilities management.

This statement was followed by the following note: "If you do not keep the budget in public operations, you have no career opportunity", which was a common reflection of the interviewees, and all new measures were eventually discussed in terms of how they could be calculated to create a (financial) benefit.

The formation of the project team included the recruitment of people from different organizations, bringing into the project team different accentuated logics and priorities. Here, the interactions behind the actual decision-making seemed to be mediated by personal relations as such, rather than the content of the logics that these persons represented. The CA was chosen as the "pilot CA" was selected on such a basis as the particular facility manager who represented this CA was considered "a little bit better" than the rest. Thus, in this sense, "to individuate" was used in two, seemingly contrasting ways. On the one hand, persons who represented a logic deemed too difficult to integrate were removed from the team (i.e. the sustainability manager) and, thus, the vicinity of the change progress as well; on the other hand, in other instances, interpersonal "chemistry" was prioritized over any particular logic. The clearest way to distinguish between these different uses was that the navigator chose one over the other on the basis of their immediate appropriateness to progress in the change project. The main goal was that the members should work well together and facilitate collaboration across organizational borders, also enabling new practices to emerge that were considered legitimate by the wider organization and institutional context.

We also note that the navigator was tentative towards the responses and feelings by a specific group of organizational members, i.e. (technical oriented) facilities managers and technical engineers whose support was crucial to implement new practices.

The current organizational logic when the strategy project was initiated was a shortterm, project-practice perspective: a "patch and mend" logic. This meant that the common 
work practice was reactive, ad hoc, and short-sighted problem-solving to handle the most acute problems. There were no systems or organizational processes for long-term planning and management. This has resulted in frustration, given that several professionals, including facilities managers, not have been able to work according to their professional training: "[... . we could only 'put out fires' and handle the most acute things; thus, we could not work according to our professional training", said one FM.

The navigator was able to capture the frustration experienced by the facilities managers. When presenting the new ideas connected to the strategy project, the navigator emphasized the long-term perspectives foregrounded by the project, thus indicating to the more technically oriented FMs and engineers that, from here on, they would work more in accordance with their formal training and professional logics. The (technical) FMs and engineers expressed that it would be "a relief" to work according to strategic facilities management; this new way was really "the obvious and natural" way to perform as an FM/engineer and was a clear contrast to the current "ad-hoc" mentality. By being zoomed in, the navigator was well-attuned to capture the current frustration among these individuals in PublicPrem and managed to gain a substantial level of support for the new proposed practices that were better aligned with their inherent wants and needs.

Thus, "to individuate" refers to two slightly different enactments in practice depending on whether it is in relation to the pilot-project group or in relation to the strategy project's general development/implementation. To individuate in relation to the strategy project represented two different facets, both interpreted in the way that favoured the project the most. For the second part, individuate refers to the ability to capture a sense of frustration amongst individuals. Taken together, the two parts show the ability to "zoom in" and be attentive to individual differences as well as to separate logics from persons and current work practices from the needs and wants of individuals.

\section{Zooming out}

Adapting to the various parts of the organization and its surroundings. As the project progressed, the answers about what the main purpose of "strategic facilities management" was varied depending on who you asked, where this person worked and when you asked $\mathrm{him} / \mathrm{her}$. Thus, strategic facilities management was an ambiguous concept, flexible enough to fit the needs and preferences of different people in PublicPrem.

This can be exemplified by the plan for evacuation into existing buildings during renovation and rebuilding, instead of using temporary pavilions. This plan was foregrounded by the strategy project and was an outcome of negotiations concerning the tensions in the overlay of multiple logics in PublicPrem and the ability of the navigator to integrate them. A necessary condition for being able to evacuate into existing buildings was to locate empty spaces, enabled by the very idea of more strategic and comprehensive facilities planning: "PublicPrem now has a more holistic "picture" regarding their building stock" (FM). Additionally, by evacuating into existing buildings, PublicPrem did not need to rent as many energy-consuming pavilions and, therefore, could address the concerns of those in PublicPrem who felt strongly about the energy aspect of the strategy project, such as the head of PublicPrem. In his view, the strategy project was, foremost, linked to a general "environmentally friendly" agenda, with the Head of PublicPrem stating that: "the proposed evacuation will demand for less usage of temporary buildings (pavilions), which are extremely bad for the environment!". In line with these propositions, the navigator managed to retain the support of the highest organizational levels, even though he personally believed that "the strategy project [...] is not so much related to these environmental goals and those things". Being zoomed out to be open to a multitude of 
$\mathrm{F}$

$39,11 / 12$

752

different stakeholders and ILs was a means of maintaining an ongoing and broad mandate for the strategy project - although it was clear that the navigator himself was not personally committed to all its aspects. For him, the financial aspects were the most prominent; not renting pavilions meant saving money, something the navigator said he enjoyed: "working with strategic facilities management has been great since it gave me with the possibility to help the city save money". Keeping the project open to different interpretations enabled several people to believe it was their concern, and the support and interest ranged from the operational to managerial levels.

Knowledge of "the nexus" led to retaining certain practices and creating others: through language, symbols and actions, the navigator adjusted his presentations throughout the organization. The navigator soon realized that the politicians who gave the initial directives would not accept a proposal that accounted only for energy efficiency, as he knew very well that the first and foremost conducted practices associated with financial logic. Therefore, the first time strategic facilities management was presented to public officers (among them, the city's financial director), the financial manager was in charge of the presentation, and the navigator played a background role. The financial dimensions/logic of the strategy project was endorsed by this opening line from the financial manager: "In the end, it is all pennies and dimes; that is not actually what we should be talking about, or working with, but that is how it goes". Thus, in meetings with politicians and laypersons, the financial aspects of the strategy project were emphasized. However, to promote strategic facilities management at the operational level of the organization, the navigator made the presentations himself, and the strategic dimensions were emphasized to a larger extent, such as practices associated with long-term planning, thus deviating from the "patch and mend" logic. Thus, the navigator had a clear sense of the organizational nexus and the "strongholds" of the different ILs.

Emphasizing collective efforts. Once the members of the pilot-project team had established an initial consensus and a comfort level based on personal relationships, they seemed to gradually turn their attention to their collective efforts and together promoted practices associated with a new strategic long-term logic, represented in the ways in which the organizational members described their tasks, their environment and the physical aid that was at their disposal. During the meetings at the later stages of the project, an emphasis was placed on mutual core values, which included, for instance, the development and introduction of practices that were related to the new emerging strategic and long-term logic. The practices associated with this logic had a strong collective bearing within the project team, but these were yet to be presented to the permanent organization. While doing this, the collective efforts were emphasized as the strategy project was presented to employees at the CAs and FMs at PublicPrem. During these episodes, the navigator spoke exclusively in terms of "we", "we in the project team have together achieved this", "we propose this", "we believe that". Thus, instead of dwelling on their differences (which, indeed, did exist), he "zoomed out" and unified the group by focusing on their collective visions and ideas and their common interest in "strategic" work.

During the meetings at the later stages of the project, an emphasis was placed on mutual core values, which included, for instance, the new more strategic and long-term logic. Issues regarding how to share important information (that was not possible today) were resolved by referring to a joint IT system - a system that the project team hoped would be developed in the future.

Another factor that seemed to strengthen the collective was their common counterparts. Thus, besides the IT system, what also joined the pilot-project group was the focus on their common counterpart, i.e. the politicians and their strong dislike for the previously used pavilions. When the navigator presented the strategy project to the stakeholders, whose approval he needed, the team spirit was strengthened by a kind of joke that resonated strongly for all of them: "one should quit one's job and become a person who rents out 
pavilions instead; that would create a much greater income [laughter]". This lived on as a joke that defined the collective vis-à-vis the politicians as another collective counterpart.

\section{Discussion}

The in-depth case study explored in this paper foregrounds a sector-specific understanding of the multidimensional challenges faced by individual actors working to improve practices related to the management of the public building stock (Boyd and Schweber, 2017; Hill et al., 2013; Ramskov-Galamba and Nielsen, 2016). Drawing on an IW lens (Lawrence and Suddaby, 2006; Campbell, 2017), the aim was to unpack the complexity and situated nature of the work experienced by the actors themselves rather than to identify any best practice for strategic public facilities management (Hopland and Kvamsdal, 2019).

The findings show how the navigator, in the early stages of the strategy project, was first and foremost using what we referred to as a "zoomed-in" approach, being particularly attentive to the details of the project and its members but also to the concerns of various professional groups. Later in the process, once the project team was fully established, the navigator switched the focus as he began to "zoom-out", paying more attention to the broader institutional context.

While it is possible to discern a certain order in "the navigator's overall responses, it is also important to acknowledge the more "messy" and contradictory nature of his work. In the early phases of the project, when "the navigator" foremost worked in a "zoomed in" mode, he seemed to be making many decisions based on personal characteristics, rather than on an overall idea of integrating multiple ILs. On the one hand, he excluded certain individuals from the project team based on the accentuated logic they represented (e.g. sustainability experts), while on the other, he invited others to participate based merely on their personal characteristics. While strong "interpersonal chemistry" can, indeed, be a compelling criterion when gathering a strong team, it is certainly a lot vaguer in regard to the representation of the multitude of ILs that, allegedly, need equal consideration to be transformed into more strategic and integrated management of building stocks (Junghans, 2013; Jensen et al., 2018; Olsson et al., 2015; Bröchner et al., 2019).

The situated nature of IW in PFMOs (Boyd and Schweber, 2017) is, thus, perhaps best described as a series of purposive yet ad hoc responses (Powell and Colyvas, 2013; Lawrence et al., 2010; Zietsma and McKnight, 2009), often geared to suit the immediate ends of the institutional worker rather than any normative bird's-eye view of institutional change or neatly ordered framework to rely on (Castán Broto, 2019). During those episodes when the navigator did, indeed, take the larger perspective into consideration, it still appeared to be a pragmatic maneuver to support immediate progress in his project rather than a clear and ordered view of how tomorrow's facility management should look like, if ones analyze and considers it from the outset (Bröchner et al., 2019).

The findings show how the complex institutional landscape that embeds PFMOs induces the responsible actors to become navigators when attempting to legitimize new practices and organizational change. Going into the strategy project, PublicPrem had afforded the navigator a generous maneuvering space to develop his ideas for new and improved organizational practices. The early stages of the strategy project were, therefore, preconditioned by organizational legitimacy. However, this legitimacy needed to be constantly reaffirmed and negotiated as the project progressed, especially in the later stages when the project deliveries (i.e. suggestions for change) needed to be weighed against, prioritized, and embedded within the landscape of existing IL. Table 4 highlights the ILs that the navigator needed to take into consideration while developing and attempting to implement new practices. In line with Goodrick and Reay (2011), Lindberg (2014), 
$\mathrm{F}$

$39,11 / 12$

754

Venkataraman et al. (2016) and Fred (2019), it was clear that these logics were addressed differently at different stages of the project and at different places in the organizational nexus (Hemme et al., 2020).

Even though scholars have begun to study how multiple ILs play out in practice during times of institutional change (Lindberg, 2014), the dominant view seems to continue to conceive of institutional change as a balancing act between two general contrasting logics, that is, to focus on dichotomies. In the field of institutional studies, it has been most common to consider institutions from afar (i.e. fully zoomed-out) (Zilber, 2013) and to conceive of the challenge of institutional change as the process of replacing an old IL for another, newer one (Thornton and Ocasio, 2013). Such a focus on institutional dichotomies is also readily discernable within the growing research agenda on sustainability and "green buildings", where sustainability most often is considered as contrasting a certain dominating IL relating to financial measurements (Dahlman and Grosvold, 2017). This notion of dichotomies is, indeed, also dominating the studies of facility and construction management, where the practical challenges usually are portrayed and conceptualized as juggling, first and foremost, two contrasting logics such as the short and the long term (Barett, 2000), the technical and the social (Nielsen et al., 2016), the financial and the sustainable (Thoresson, 2015; Ramskov-Galamba and Nielsen, 2016) or the financial and the social (Troje and Gluch, 2019). By exploring IW as it unfolds on the micro-levels in these contexts, this paper illustrates how the actual challenge is less about weighing and managing various dichotomies and more about how to navigate a multitude of different logics in practice. To be aware of this, we argue is crucial to achieve change in PFMOs. Being reflective and aware of the behaviours and practices associated with a logic is necessary to be able to choose both to follow it or not to follow it (the navigator chose to ignore the "public" logic but adhered to the "financial" ditto, to move the change process forward) i.e. be aware of which practices to maintain and which to disrupt. Our findings point to the fact that it is not the logics presence per se that determine the outcome of new practice implementation, rather how these logics are acted upon, in practice (Hemme et al., 2020).

\section{Managerial implications and future studies}

PFMOs seem to have a hard time to realize a more "strategic facilities management" (Hopland, 2016; Uotila et al., 2020) despite good efforts, and despite scattered approval for such initiatives. In PublicPrem, this change was represented by a project (i.e. the strategy project), that needed to be aligned with the already prevailing logic in the organization, i.e. the short-term, project-practice "patch and mend" logic. However, for change to be implemented, it need not be isolated in the form of a project since the ideas put forward by the navigator required changes in various parts of the organizational nexus of the PFMO, and they needed ongoing elaboration and legitimization work beyond the project's time frame to be embedded in the organization and its surroundings.

The present work adds to a growing number of studies that have explored emerging roles in the built-environment sector and emphasized the need for new types of expertise, such as communicative skills (Ludvig et al., 2013), sustainability knowledge (Nielsen et al., 2016) and an understanding of social (sustainability) issues (Troje and Gluch, 2019). In addition to these competences, our results lend weight to the need to develop officials' competence to navigate multiple logics. Herein lies the ability to communicate but also to have a broad knowledge of the organizational and institutional sourroundings, to know what guides different stakeholder groups, and to be aware of the core principles underlying situated practices, i.e. "how things are done", in various different work contexts. 
The idea put forward by the navigator in our case was an integrated type of practice that brought several perspectives into consideration. While both enabling and accepting ambiguity indeed seemed necessary to move the change process forward, the vagueness of the concept "strategic facilities management" would perhaps made it difficult to implement in the later stages, once it was going to be operationalized. Thus, it would be valuable for future studies to focus on the tensions between the measures needed to be taken to legitimize new practices across PFMOs in the beginning of a change effort and the later implementations and organizational embedding of the practices associated with the change effort.

\section{Conclusions}

Previous studies of public facilities management have stopped short of understanding the work of officials in PFMOs as situated in networks of practices and logics. To address this gap, this paper draws on practice-based institutionalism to explicate the nature of the IW underlying the development and implementation of new practices relating to a more strategic and long-term public facilities management.

Officials in PFMOs who are responsible for developing and implementing such change, need to navigate and integrate multiple logics in practice; to do this they must be able to "zoom in" and "zoom out", i.e. be flexible and able to adjust to situated circumstances; and engage in work that aims at creating, maintaining and disrupting institutional practices.

\section{Note}

1. In 2011, a new law was established in Sweden stating that public housing companies must act according to commercial/business principles (Law, 2010, p. 879).

\section{References}

Barett, P. (2000), "Achieving strategic FM through strong relationship”, Facilities, Vol. 18 Nos 10/11/12, pp. 421-426.

Battilana, J. and D'Aunno, T. (2010), "Institutional work and the paradox of embedded agency", in Lawrence, T.B., Suddaby, R. and Leca, B. (Eds), Institutional Work Actors and Agency in Institutional Studies of Organizations, Cambridge University Press, pp. 31-58.

Battilana, J., Leca, B. and Boxenbaum, E. (2009), "How actors change institutions: towards a theory of institutional entrepreneurship", Academy of Management Annals, Vol. 3 No. 1, pp. 65-107.

Bordass, B. and Leaman, A. (2013), "A new professionalism: remedy or fantasy?”, Building Research and Information, Vol. 41 No. 1, pp. 353-360.

Boyd, P. and Schweber, L. (2017), "Unintended consequences: institutional artefacts, closure mechanisms and the performance gap", Building Research and Information, Vol. 46 No. 1, pp. 10-22.

Bröchner, J., Haugen, T. and Lindkvist, C. (2019), "Shaping tomorrow's FM”, Facilities, Vol. 37 Nos 7/8, pp. 366-380.

Campbell, L.Z. (2017), "An exploration of how research can aid the development of facilities management”, Facilities, Vol. 35 Nos 5/6, pp. 356-366.

Castán Broto, V. (2019), "Climate change politics and the urban contexts of messygovernmentalities", Territory, Politics, Governance, Vol. 8 No. 2, pp. 1-18.

Czarniawska, B. (2014), Social Science Research: From Field to Desk, SAGE Publications. 
$39,11 / 12$

Dahlman, F. and Grosvold, J. (2017), "Environmental managers and institutional work: reconciling tensions of competing ILs", Business Ethics Quarterly, Vol. 27 No. 2, pp. 263-291.

Dubois, A. and Gadde, L.-E. (2002), "Systematic combining: an abductive approach to case research", Journal of Business Research, Vol. 55 No. 7, pp. 553-560.

Dunn, M.B. and Jones, C. (2010), "ILs and institutional pluralism: the contestation of care and science logics in medical education 1967-2005”, Administrative Science Quarterly, Vol. 55 No. 1, pp. 114-149.

Dyer, W.G. and Wilkins, A.L. (1991), "Better stories, not better constructs, to generate better theory: a rejoinder to Eisenhardt", Academy of Management Review, Vol. 16 No. 3, pp. 613-619.

Flick, U. (2014), An Introduction to Qualitative Research, 5th ed., Sage Publications.

Flyvbjerg, B. (2006), "Five misunderstandings about case-study research", Qualitative Inquiry, Vol. 12 No. 2, pp. 219-245.

Fred, M. (2019), "Local government projectification in practice - a multiple institutional logics perspective", Local Government Studies, Vol. 46 No. 3, pp. 351-370.

Friedland, R. and Alford, R. (1991), "Bringing society back", in Powell, W.W. and DiMaggio, P.J. (Eds), The New Institutionalism in Organizational Analysis, University of Chicago Press, pp. 232-263.

Galamba, K.R., Nielsen, S.B. and Aagaard Nielsen, K. (2012), "Public facilities management and action research for sustainability", doctoral thesis, Technical University of Denmark.

Gioia, D.A., Corley, K.G. and Hamilton, A.M. (2013), "Seeking qualitative rigor in inductive research: notes on the Gioia methodology", Organizational Research Methods, Vol. 16 No. 1, pp. $15-31$.

Gluch, P. and Bosch-Sijtsema, P. (2016), "Conceptualizing environmental expertise through the lens of institutional work", Construction Management and Economics, pp. 1-14.

Gluch, P. and Svensson, I. (2018), "On the nexus of changing public facilities management practices: purposive and co-creative actions across multiple levels", Construction Management and Economics, Vol. 36 No. 5, pp. 259-275.

Goodrick, E. and Reay, T. (2011), "Constellations of ILs: changes in the professional work of pharmacists", Work and Occupations, Vol. 3 No. 38, pp. 372-416.

Hampel, C.E., Lawrence, T.B. and Tracey, P. (2017), "Institutional work: taking stock and making it matter", in Greenwood, R., Oliver, C., Lawrence, T.B. and Meyer, R.E. (Eds), SAGE Handbook of Organizational Institutionalism, 2nd ed., Sage Publications, pp. 558-590.

Haugen, T.B. and Klunseth, N.J. (2017), "In-house or outsourcing FM services in the public sector: a review of 25 years research and development", Journal of Facilities Management, Vol. 15 No. 3, pp. 262-284.

Hemme, F., Bowers, M.-T. and Todd, J.-S. (2020), "Enacting logics in practice: a critical realist perspective", Journal of Change Management, Vol. 20 No. 2, pp. 99-122.

Higginbottom, G.M., Pillay, J.J. and Boadu, N.Y. (2013), "Guidance on performing focused ethnographies with an emphasis on healthcare research", Qualitative Report, Vol. 18 No. 9, pp. 1-6.

Higham, A., Fortune, C. and James, H. (2015), "Life cycle costing: evaluating its use in UK practice", Structural Survey, Vol. 33 No. 1, pp. 73-87.

Hill, S., Lorenz, D., Dent, P. and LüTzkendorf, T. (2013), "Professionalism and ethics in a changing economy", Building Research and Information, Vol. 41 No. 1, pp. 8-27.

Hopland, A.O. (2016), "Long-run relationship between investment and maintenance in local governments", Facilities, Vol. 34 Nos 11/12, pp. 703-722.

Hopland, A.O. and Kvamsdal, S. (2019), "Building conditions in Norwegian local governments: trends and determinants", Facilities, Vol. 37 Nos 3/4, pp. 141-156.

Jensen, P.A., Maslesa, E. and Brinkø Berg, J. (2018), "Sustainable building renovation: proposals for a research agenda”, Sustainability, Vol. 10 No. 12, pp. 46-77. 
Junghans, A.O.E. (2013), "Decision support model for energy-efficient improvement of entire building stocks", Facilities, Vol. 31 Nos 3/4, pp. 173-184.

Karvonen, A. (2013), “Towards systemic domestic retrofit: a social practices approach”, Building Research and Information, Vol. 41 No. 5, pp. 563-574.

Kaya, S., Heywood, C., Arge, K., Brawn, G. and Alexander, K. (2005), "Raising facilities management's profile in organisations: developing a world-class framework", Journal of Facilities Management, Vol. 3 No. 1, pp. 65-82.

Lawrence, T.B. and Suddaby, R. (2006), "Institutions and institutional work", in Clegg, S.R., Hardy, C., Lawrence, T.B. and Nord, W.R. (Eds), Sage Handbook of Organizations Studies, 2nd ed., Sage, pp. 215-254.

Lawrence, T.B., Suddaby, R. and Leca, B. (2010), "Introduction: theorizing and studying institutional work", in Lawrence, T.B., Suddaby, R. and Leca, B. (Eds), Institutional Work Actors and Agency in Institutional Studies of Organizations, Cambridge University Press, pp. 1-27.

Lawrence, T., Suddaby, R. and Leca, B. (2011), "Institutional work: refocusing institutional studies of organization”, Journal of Management Inquiry, Vol. 20 No. 1, pp. 52-58.

Lindberg, K. (2014), "Performing multiple logics in practice", Scandinavian Journal of Management, Vol. 30 No. 4, pp. 485-497.

Lounsbury, M. and Crumley, E.T. (2007), "New practice creation: an institutional perspective on innovation”, Organization Studies, Vol. 28 No. 7, pp. 993-1012.

Ludvig, K., Stenberg, A. and Gluch, P. (2013), "The value of communicative skills for developing an energy strategy", Building Research and Information, Vol. 41 No. 6, pp. 611-621.

Nielsen, S.B., Sarasoja, A.-L. and Galamba, K.R. (2016), "Sustainability in facilities management: an overview of current research", Facilities, Vol. 34 Nos 9/10, pp. 535-563.

Olsson, S., Malmqvist, T. and Glaumann, M. (2015), "Managing sustainability aspects in renovation processes: interview study and outline of a process model”, Sustainability, Vol. 7 No. 6, pp. 6336-6352.

Palm, J. and Reindl, K. (2016), "Understanding energy efficiency in Swedish residential building renovation: a practice theory approach”, Energy Research and Social Science, Vol. 11, pp. 247-255.

Palm, J. and Reindl, K. (2017), "Understanding barriers to energy-efficiency renovations of multifamily dwellings", Energy Efficiency, Vol. 11 No. 1, pp. 53-56.

Pardalis, G., Mahpatra, K. and Mainali, B. (2019), "Swedish construction MSEs: simply renovators or renovation service innovators?”, Building Research and Information, Vol. 48 No. 1, pp. 67-83.

Pemer, F. and Skjølsvik, T. (2018), "Adopt or adapt? Unpacking the role of institutional work processes in the implementation of new regulations", Journal of Public Administration Research and Theory, Vol. 41 No. 5, pp. 138-154.

Powell, W.W. and Colyvas, J.A. (2013), "Microfoundations of institutional theory", in Greenwood, R., Oliver, C., Sahlin, K. and Suddaby, R. (Eds), Sage Handbook of Organizational Institutionalism, Sage.

Ramskov-Galamba, K.R. and Nielsen, S.B. (2016), "Towards sustainable public facilities management: collective building of capabilities”, Facilities, Vol. 34 Nos 3/4, pp. 177-195.

Reay, T. and Jones, C. (2016), “Qualitatively capturing ILs”, Strategic Organization, Vol. 14 No. 4, pp. 441-454.

Schweber, L. and Leiringer, R. (2012), "Beyond the technical: a snapshot of energy and buildings research", Building Research and Information, Vol. 40 No. 4, pp. 481-492.

Smets, M. and Jarzabkowski, P. (2013), "Reconstructing institutional complexity in practice: a relational model of institutional work and complexity”, Human Relations, Vol. 66 No. 10, pp. 1279-1309.

Smets, M., Aristidou, A. and Whittington, R. (2017), "Towards a practice-driven institutionalism", in Greenwood, R., Oliver, C., Lawrence, T.B. and Meyer, R. (Eds), Sage Handbook of Organizational Institutionalism, Sage. 
Svensson, I. (2018), “Changing practices for public facilities management", Licentiate thesis, Gothenburg, Digitaltryck.

Thoresson, J. (2015), "Omställning-tillväxt-Effektivisering energifra ${ }^{3}$ gor vid renovering av flerbostadshus, (Conversion - growth - efficiency: energy issues when renovating apartment buildings)", Doctoral Thesis, Linköping University, Linköping.

Thornton, P.H. (2002), "The rise of the corporation in craft industry: conflict and conformity in institutional logics.", Academy of Management Journal, Vol. 45 No. 1, pp. 81-101.

Thornton, P.H. and Ocasio, W. (2013), "Institutional logics", in Greenwood, R., Oliver, C., Sahlin, K. and Suddaby, R. (Eds), Sage Handbook of Organizational Institutionalism, Sage.

Troje, D. and Gluch, P. (2019), "Populating the social realm: new roles arising from social procurement", Construction Management and Economics, Vol. 38 No. 1, pp. 55-70.

Tucker, M., Rayme, M. and Masuri, A. (2016), "The rationale to integrate facilities management into the development process", Property Management, Vol. 34 No. 4, pp. 332-344.

Uotila, U., Saari, A. and Junnonen, J.-M. (2019), "Municipal challenges in managing a building with noted health symptoms", Facilities, Vol. 38 Nos 5/6, pp. 365-377.

Venkataraman, H., Vermeulen, P., Raaijmakers, A. and Mair, J. (2016), "Market meets community: ILs as strategic resources for development work", Organization Studies, Vol. 37 No. 5, pp. 709-733.

Zietsma, C. and McKnight, B. (2009), "Building the iron cage: institutional creation work in the context of competing proto-institutions", in Lawrence, T.B., Suddaby, R. and Leca, B. (Eds), Institutional Work Actors and Agency in Institutional Studies of Organizations, Cambridge University Press, pp. 143-177.

Zilber, T.B. (2013), "Institutional work and institutional work: should they be agreed?", Research in the Sociology of Organizations, Vol. 39, pp. 77-96.

Zilber, T.B. (2020), "The methodology/theory interface: ethnography and the microfoundations of institutions", Organization Theory, Vol. 1 No. 2, pp. 1-27.

\section{Further reading}

Hartmann, A., Reymen, I. and Van Oosterom, G. (2008), "Factors constituting the innovation adoption environment of public clients", Building Research and Information, Vol. 36 No. 5, pp. 436-449.

\section{Corresponding author}

Ingrid Svensson can be contacted at: ingrid.svensson@chalmers.se

For instructions on how to order reprints of this article, please visit our website: 